\title{
Self-perception of knowledge and adherence reflecting the effectiveness of antiretroviral therapy
}

\author{
This article was published in the following Dove Press journal: \\ Patient Preference and Adherence \\ 13 September 2016 \\ Number of times this article has been viewed
}

\section{Carolina Dagli-Hernandez' \\ Rosa Camila Lucchetta' \\ Tales Rubens de $\mathrm{Nadai}^{2}$ \\ José Carlos Fernandez \\ Galduróz ${ }^{3}$ \\ Patricia de Carvalho \\ Mastroianni' \\ 'Department of Drugs and \\ Medications, School of Pharmaceutical \\ Sciences of the UNESP - Univ \\ Estadual Paulista, Araraquara, \\ ${ }^{2}$ Department of Surgery and Anatomy, \\ Americo Brasiliense State Hospital, \\ ${ }^{3}$ Department of Psychobiology, \\ Universidade Federal de São Paulo \\ (UNIFESP), São Paulo, Brazil}

Correspondence: Patricia de Carvalho Mastroianni

Department of Drugs and Medications, School of Pharmaceutical Sciences of the UNESP - Univ Estadual Paulista, Rodovia Araraquara - Jaú, km I, Araraquara, São Paulo, CEP |480|-902, Brazil

Tel +55 I6 330। 6977

Fax +55 I6 33220073

Email patriciamastroianni@yahoo.com.br

Tales Rubens de Nada

Department of Surgery and Anatomy, Americo Brasiliense State Hospital, Alameda Aldo Lupo 1260, Américo Brasiliense, São Paulo |4820-000, Brazil Email talesusp@yahoo.com.br
Objectives: To evaluate which indirect method for assessing adherence best reflects highly active antiretroviral therapy (HAART) effectiveness and the factors related to adherence.

Method: This descriptive, cross-sectional study was performed in 2012 at a reference center of the state of São Paulo. Self-report (simplified medication adherence questionnaire [SMAQ]) and drug refill parameters were compared to the viral load (clinical parameter of the effectiveness of pharmacotherapy [EP]) to evaluate the EP. The "Cuestionario para la Evaluación de la Adhesión al Tratamiento Antiretroviral" (CEAT-VIH) was used to evaluate factors related to adherence and the EP and, complementarily, patient self-perception of adherence was compared to the clinical parameter of the EP.

Results: Seventy-five patients were interviewed, 60 of whom were considered as adherent from the clinical parameter of the EP and ten were considered as adherent from all parameters. Patient self-perception about adherence was the instrument that best reflected the EP when compared to the standardized self-report questionnaire (SMAQ) and drug refill parameter. The level of education and the level of knowledge on HAART were positively correlated to the EP. Forgetfulness, alcohol use, and lack of knowledge about the medications were the factors most frequently reported as a cause of nonadherence.

Conclusion: A new parameter of patient self-perception of adherence, which is a noninvasive, inexpensive instrument, could be applied and assessed as easily as self-report (SMAQ) during monthly drug refill, since it allows monitoring adherence through pharmaceutical assistance. Therefore, patient adherence to HAART could be evaluated using self-perception (CEAT-VIH) and the viral load test.

Keywords: health literacy, anti-HIV agents, patient compliance, antiretroviral therapy, highly active, acquired immunodeficiency syndrome

\section{Introduction}

Since its introduction in 1996, the highly active antiretroviral therapy (HAART) has decreased the morbidity and mortality due to the acquired immunodeficiency syndrome (AIDS). ${ }^{1}$ However, the maximum effectiveness of the treatment is ensured not only by effective and potent drugs, but also by patient adherence to the therapy.

Poor adherence is a remarkable problem as it increases the chance of virologic failure, decreasing the recovery of CD4 cells, increasing viral load and, therefore, increasing the risk of death. Another important consequence is the increased possibility of mutations resistant to currently available drugs. ${ }^{2}$

Factors related to poor adherence comprise treatment, health care service, patient, and lifestyle characteristics. Treatment characteristics include inflexible dosing schedules, adverse events, long periods of treatment (over 6 years), and the concomitant use of other drugs in addition to antiretroviral drugs. Among health care 
service characteristics are the impaired access to health care services, which makes it difficult for the patient to be followed by a health care professional; and smaller services with small staff numbers, which have shown difficulties in standardizing and supervising the performance of health care professionals, as well as promoting technical discussions. ${ }^{3}$ Forgetfulness, missing medical appointments, demotivation, and the educational level of the patient are also associated with poor adherence. Factors related to the lifestyle are the use of alcohol and injectable drugs, travels, social isolation, depression, and stress, among others. ${ }^{4-8}$

According to Bartlett, ${ }^{9}$ an adherence $\geq 95 \%$ is required for viral suppression; however, $40 \%-60 \%$ of patients adhere $<90 \%$ in Brazil, tending to decrease over time. ${ }^{3}$ Nevertheless, it has been shown that a moderate adherence $(<95 \%)$ to more powerful regimens, such as protease inhibitors (PI) and non-nucleoside reverse transcriptase inhibitors, does not significantly affect a decreased viral load, ${ }^{10,11}$ and the potential to develop mutations is lower in schemes containing PI. ${ }^{2}$

It is recommended assessing adherence to pharmacotherapy by two methods, ${ }^{12}$ which may be direct (monitoring plasma concentration of the drug or its metabolites), that tend to be more accurate, but expensive; or indirect (selfreporting through questionnaires, pill counting, drug refill), and cheaper, but require more time to apply and tend to be less accurate. The viral load is one of the most valuable measures for evaluating disease progression and anti-HIV treatment effectiveness. ${ }^{13}$

Considering that adherence to therapy is an important part of the treatment and that monitoring patient adherence is essential to ensure the maximum effectiveness of the pharmacotherapy, it is important to verify whether the inexpensive methods truly reflect viral suppression and which patientrelated factors may influence the effectiveness. Therefore, this study aimed to: 1) evaluate which indirect method for assessing adherence best reflects HAART effectiveness, and 2) which sociodemographic variables and factors are related to adherence and the effectiveness of pharmacotherapy (EP).

\section{Materials and methods}

This descriptive, cross-sectional study was conducted in 2012 at the Special Health Care Service of Araraquara, responsible for sexually transmitted infections/AIDS program in the city of Araraquara, Sao Paulo State, Brazil. Patients $>18$ years who used HAART and had a medical appointment scheduled in the period of the study were included. Patients who died during the study were excluded.
Two indirect methods for assessing adherence to pharmacotherapy were evaluated: drug refill and self-report according to the "simplified medication adherence questionnaire" (SMAQ). ${ }^{14}$ This SMAQ includes the following questions:

1. Do you ever forget to take your medications?

2. Do you always take your medications at the time indicated?

3. Do you ever stop taking the medication when you feel bad?

4. Did you forget to take your medication during the weekend?

5. In the last week, how many times did you not take a dose?

6. In the last 3 months, how many full days did you not take the medication?

These two methods were compared with the clinical parameter of the EP, defined as a viral load of $<400$ copies $/ \mathrm{mL}$.

To evaluate factors and sociodemographic variables related to adherence and the EP, the Brazilian adapted version of the "Cuestionario para la Evaluación de la Adhesión al Tratamiento Antiretroviral" (CEAT-VIH) was used. ${ }^{15}$ This questionnaire assesses not only patients' satisfaction, difficulties, information, and conception about their therapy, but also their self-perception of adherence. Therefore, complementarily, patient self-perception of adherence was also compared to the clinical parameter of the EP.

Data were collected on one individual interview conducted after the patient's medical appointment. The data collection instrument was a structured form, previously applied to four patients for adequacy, that contained questions including: I - patient characteristics (initials, marital status, sex, date of birth, and education level); II - evaluation of patient adherence to therapy (self-report), according to SMAQ; III - current pharmacotherapy; and IV - evaluation of patient self-perception of adherence, as well as of factors related to poor adherence based on CEAT-VIH.

Viral load data from the last 6 months and drug refill data from the last 3 months were collected using the Drug Logistics Control System (SICLOM).

Patients were considered adherent according to the following parameters:

- Viral load (clinical parameter of the EP): the patient had $<400$ copies/mL or had decreased the viral load by one-third from the last count. ${ }^{16}$

- Self-report parameter using SMAQ: the patient responded negatively to questions 1,3 , and 4 , and missed doses less than two times in the last week and $<2$ complete days in the last 3 months. ${ }^{14}$ 
- Drug refill parameter: the patient delayed monthly drug refill by not $>2$ days. ${ }^{16}$

For statistical analyses, we used the StatPlus ${ }^{\mathbb{B}}$ (AnalystSoft, Walnut, CA, USA) and Statistica ${ }^{\circledR}$ (StaSoft Inc., Tulsa, OK, USA) softwares to apply the chi-square test $(95 \%$ confidence interval), to identify factors and sociodemographic variables that influence pharmacotherapy effectiveness and verify which method for assessing adherence is mostly correlated to the EP. When the expected frequencies were $<5$, we applied the Yates correction.

The project was approved by the Research Ethics Committee of the Federal University of São Paulo/Hospital São Paulo (No 1365/09). All patients signed an informed consent before participating in this study.

\section{Results}

In the period of the study, 455 patients were registered in the service: only 98 of them met the inclusion criteria; 75 $(76.5 \%)$ of these agreed to participate in the interview and 23 declined their consent. Fourteen of these were considered nonadherent from all parameters, 65 were considered nonadherent from at least one of the parameters and only ten were considered adherent from all parameters (Figure 1). The sociodemographic characteristics of the patients are described in Table 1.

Patients deemed nonadherent from self-report parameter (52) were asked about the reasons for not taking drugs properly. Forgetfulness (26) and alcohol use (12) were the most frequently reported reasons for nonadherence, followed by the lack of drugs (eight), travels (four), and malaise (four). As strategies to remember to take the medicine, patients reported using alarms, daily pill separators, and caregivers' support.

From the responses to CEAT-VIH questionnaire, it was found that most patients believed having less or sufficient information about their drugs and properly following treatment requires a lot of effort (Table 2). As for self-perception according to CEAT-VIH, 58 patients considered themselves as fairly adherent, which strongly corresponds to the number of patients deemed adherent from the clinical parameter of the EP (viral load) (Figure 1); on the other hand, less than half were considered adherent from self-report (SMAQ) and drug refill parameters, compared to the clinical parameter.

As difficulties to adhere to treatment, patients reported the complexity of the pharmacotherapy, drug size, drug taste, the amount of drugs, and the dosing schedule.

The association between factors or sociodemographic variables and the EP was statistically tested, and only the level of education $(P=0.003)$ and the information that the patient believes to have about HAART $(P=0.009)$ showed to be correlated. The therapeutic regimen $(P=0.994)$ and the number of tablets administered daily $(P=0.282)$ did not show any statistically significant relationship with the EP (Table 1).

\section{Discussion}

Though indirect methods for assessing adherence are recommended for controlling and evaluating adherence to HAART by the sexually transmitted infections/AIDS programs of Pharmaceutical Assistance, ${ }^{17}$ our data showed that there were differences in results depending on the instrument used (Figure 1).

Among the indirect methods used in this study, the viral load is the method that best reflects the EP..$^{13,17}$ Nevertheless, it is more invasive and expensive, requires laboratory exams, and should be performed at least twice a year according to guidelines. ${ }^{17}$

It is recommended to use two methods for assessing the effectiveness of pharmacotherapy. ${ }^{12}$ The first method could be the viral load, which is the most effective for evaluating
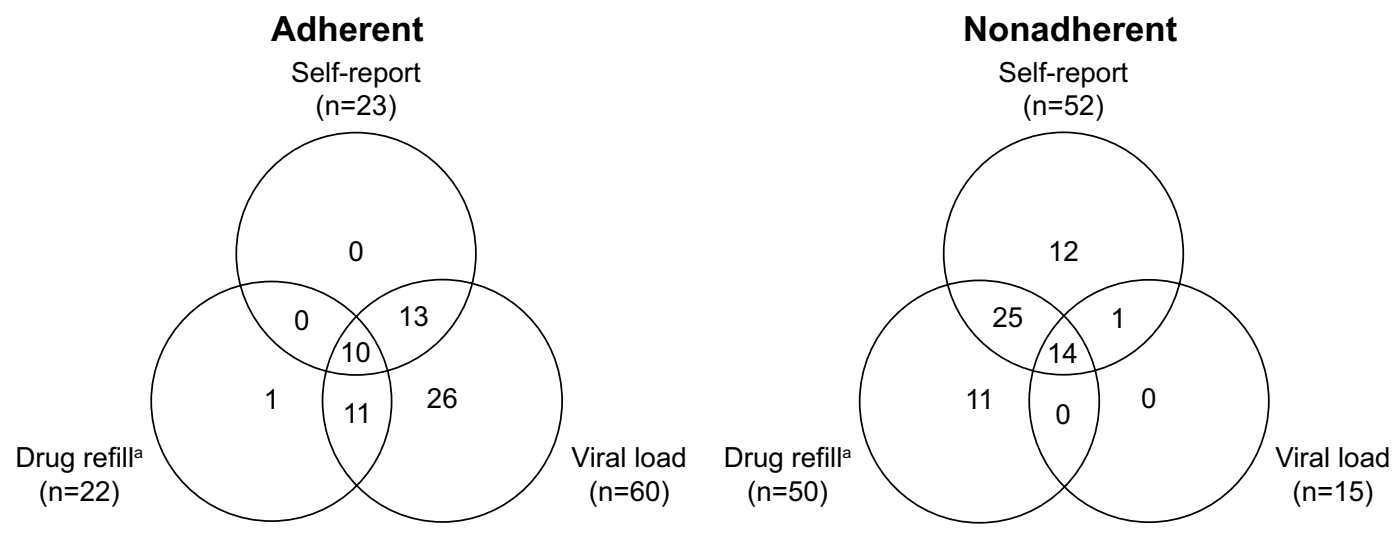

Figure I Patients considered adherent and nonadherent to HAART according to SMAQ, drug refill and viral load parameters ( $\mathrm{N}=75$ ).

Note: alt was not possible to evaluate three patients using drug refill parameter.

Abbreviations: HAART, highly active antiretroviral therapy; SMAQ, simplified medication adherence questionnaire. 
Table I Distribution of patients by sociodemographic variables and correlation with the effectiveness of pharmacotherapy, AraraquaraSão Paulo, Brazil, $2010(\mathrm{~N}=75)$

\begin{tabular}{|c|c|c|c|}
\hline $\begin{array}{l}\text { Sociodemographic } \\
\text { variables }\end{array}$ & $\mathbf{n}$ & $\begin{array}{l}\text { Effectiveness of } \\
\text { pharmacotherapy }\end{array}$ & $P$-value \\
\hline \multicolumn{4}{|l|}{ Sex } \\
\hline Male & 54 & 44 & $0.6 \mathrm{I}$ \\
\hline Female & 21 & 16 & \\
\hline \multicolumn{4}{|l|}{ Age (years) } \\
\hline $18-24$ & I & 1 & 0.28 \\
\hline $25-34$ & 2 & 2 & \\
\hline $35-44$ & 32 & 22 & \\
\hline $45-54$ & 29 & 25 & \\
\hline$>55$ & II & 10 & \\
\hline \multicolumn{4}{|l|}{ Marital status } \\
\hline Single & 26 & 20 & 0.997 \\
\hline Stable relationship & 13 & 13 & \\
\hline Married & 16 & 12 & \\
\hline Divorced & 10 & 7 & \\
\hline Widower & 10 & 8 & \\
\hline \multicolumn{4}{|l|}{ Education (years) } \\
\hline $0-4$ & 16 & 12 & $0.003^{\mathrm{a}}$ \\
\hline 5-8 (basic education) & 29 & 22 & \\
\hline 9-II (high school) & 18 & 15 & \\
\hline$>11$ & 3 & 3 & \\
\hline Not informed & 9 & 8 & \\
\hline
\end{tabular}

Note: ${ }^{a}<<0.05$.

the EP. The second method should be as efficient as the viral load and allow evaluation of adherence in an inexpensive, easy-to-apply, less invasive way; it should also allow to be applied with a higher frequency, for example during monthly drug refill. This second method could be the self-report using SMAQ or drug refill.

However, the self-report parameter has been shown to be too strict, since, according to Shuter et al ${ }^{10}$ and Bangsberg, ${ }^{11}$ an adherence of $<95 \%$ may not have a significant impact on the viral load when potent regimens, such as PI and non-nucleoside reverse transcriptase inhibitors, are used. Only one patient in our study did not use one of these regimens. Therefore, this method may be excessively rigorous for detecting nonadherence to HAART.

Drug refill parameter also underestimated the EP, probably because it was equally stringent. This parameter considers that a delay of $>2$ days in monthly drug refill already reflects nonadherence; however, the time to refill depends on the amount of dispensed units and also on the days of operation of the service. Furthermore, the lack of policies and incentives for drug fractionation prevents this method from being effective and to directly reflect adherence. ${ }^{18}$

On the other hand, patient self-perception, evaluated using CEAT-VIH, was the instrument that best reflected the EP when compared to drug refill and self-report (SMAQ) parameters. Differently from self-report, patient self-perception does not depend on a quantitative memory, but on a qualitative memory: patients classify how adherent they believe they are without needing to remember specific events, which may become a more precise assessment parameter. ${ }^{15}$

Besides, CEAT-VIH not only allows patients to evaluate and rethink about their adherence, but also allows health

Table 2 Analysis of factors that possibly influence adherence and correlation with the effectiveness of pharmacotherapy, Araraquara, Sao Paulo State, Brazil, 2010 ( $N=75)$

\begin{tabular}{|c|c|c|c|c|c|c|}
\hline \multicolumn{6}{|l|}{ Factors that possibly influence adherence } & \multirow{2}{*}{$\begin{array}{l}\text { Effectiveness of } \\
\text { pharmacotherapy } \\
P \text {-value } \\
\end{array}$} \\
\hline & & & & & & \\
\hline & Not satisfied & Indifferent & Satisfied & & & \\
\hline \multirow[t]{2}{*}{ Satisfaction with treatment } & 4 & 2 & 69 & & & 0.904 \\
\hline & Much & Moderate & None & & & \\
\hline \multirow[t]{2}{*}{ Difficulty of taking the medication } & 5 & 5 & 65 & & & 0.283 \\
\hline & None & Little & Moderate & Much & & \\
\hline Effort to properly follow treatment & 0 & 24 & 13 & 38 & & 0.593 \\
\hline Information patient believes to have about the medication & 0 & 29 & 24 & 22 & & $0.009^{a}$ \\
\hline $\begin{array}{l}\text { Information about the benefit that the use of HAART } \\
\text { can bring to health }\end{array}$ & 0 & 4 & 7 & 64 & & 0.954 \\
\hline Improvements in health after starting HAART & 0 & II & 4 & 60 & & 0.305 \\
\hline \multirow[t]{2}{*}{ Ability to continue with treatment } & 0 & 2 & 1 & 72 & & 0.865 \\
\hline & None & Little & Moderate & Considerable & Much & \\
\hline Intensity of the side effects of HAART & 48 & 13 & 8 & 1 & 5 & 0.539 \\
\hline Time spent taking the medication & 71 & 2 & 0 & 0 & 2 & 0.878 \\
\hline Evaluation of adherence to therapy & I & I & 15 & 50 & 8 & 0.694 \\
\hline
\end{tabular}

Note: ${ }^{a} P<0.05$.

Abbreviation: HAART, highly active antiretroviral therapy. 
care professionals to identify other factors possibly related to poor adherence, such as drug-related problems and adverse events. ${ }^{15}$ This way, health care professionals become capable of proposing interventions even before investigating the EP by clinical parameters. Evaluating adherence is important since asymptomatic patients do not believe in the risk of nonadherence and tend to take their medication less regularly. ${ }^{19}$

Although monitoring adherence by patient self-perception may be time-consuming, as it depends on interviews and patient availability, it may be performed during the health counseling by multidisciplinary teams. Health counseling, an interactive, two-way process that starts from patient EP and allows identifying the reasons for nonadherence, can improve patient knowledge about the therapy and the consequences of nonadherence; therefore, the patient will be more willing to adhere. ${ }^{19,20}$

In our study, a correlation between EP and the level of education was observed. Previous studies confirmed the relationship between literacy and adherence, ${ }^{21,22}$ and demonstrated that more educated patients have a higher chance to reach viral suppression than those with no or low literacy. This is because subjects with low literacy may have difficulties in understanding the guidance provided by health care professionals and, therefore, will not sufficiently adhere to treatment. ${ }^{23}$ Health literacy indicates the ability with which patients receive, process, and understand information necessary to their treatment. HIV+ patients with low health literacy generally present with low knowledge and understanding about their health condition, lower perception about the treatment, low adherence to medications and decreased immune function, and tend to be three times less adherent than those with more knowledge and understanding about HAART. ${ }^{24,25}$

Therefore, data on this study suggest that a new parameter of patient self-perception of adherence to pharmacotherapy, a noninvasive, cheap instrument, could be applied and assessed as easily as the self-report (SMAQ) parameter during monthly drug refill. This way, it allows monitoring adherence through pharmaceutical assistance, even before medical visits and routine laboratory tests, and making interventions in order to improve adherence.

As observed in the systematic review and meta-analysis of Conn et al, ${ }^{26}$ interventions to improve adherence increase significantly patient knowledge about medications, which improves their quality of life, physical ability, and symptoms. Other interventions, such as treatment simplification, also have a positive impact on morbidity and reduce treatment costs with human resources, since professionals are efficiently allocated. ${ }^{27}$ Analyses on the economic impact of the interventions to improve adherence also showed a significant decrease in costs for medical appointments and hospitalizations, though this aspect still needs further investigation. ${ }^{28,29}$

Concerning factors related to nonadherence, in our study, the reasons mainly reported in CEAT-VIH were the need of much effort to comply with the pharmacotherapy and the lack of knowledge about medications, which showed a significant correlation with the parameter of EP. Also, according to the responses to SMAQ, the mostly reported reason was forgetfulness.

These factors are probably related: a penta-continental study carried out by Nachega et $\mathrm{al}^{23}$ showed that $43 \%$ of patients admit to have forgotten at least one dose in the last month, suggesting that they possibly do not completely understand the impact of forgetting to take medications on their health. It shows that the lack of information regarding the risks of not using the medications prescribed can cause nonadherence and corroborates the results of our study. Educational interventions and pharmacotherapy management could also contribute to solve this problem. ${ }^{26}$

\section{Conclusion}

The EP was best reflected by the patient's self-perception, when compared to the standardized self-report questionnaire (SMAQ) and drug refill.

The level of education and of knowledge on HAART reported by the patient are positively correlated to the EP.

Most patients feel very satisfied and capable of following treatment, although they reported making a great effort to follow treatment properly, and recognize the benefits HAART can bring to their health and the improvements they have after beginning the therapy.

\section{Acknowledgments}

The authors thank the multidisciplinary team of the Special Service of Araraquara for collaborating and enabling this study; the financial support provided by the Program of Support to Scientific Development of the School of Pharmaceutical Sciences at the Universidade Estadual Paulista - UNESP (process no 2010/21-I); Ruth Ferreira Santos-Galduróz, for helping in the statistical analysis; and Thaís de Souza Cordeiro, for her support in the study. The authors would also like to thank FAPESP for the financial support in this project, under the grant \#2014/03468-6, São Paulo Research Foundation (FAPESP). 


\section{Author contributions}

All authors made substantial contributions to conception and design, acquisition of data, or analysis and interpretation of data; took part in drafting the article or revising it critically for important intellectual content; gave final approval of the version to be published; and agree to be accountable for all aspects of the work.

\section{Disclosure}

The authors report no conflicts of interest in this work.

\section{References}

1. Cardoso SW, Torres TS, Santini-Oliveira M, Marins LMS, Veloso VG, Grinsztejn B. Aging with HIV: a practical review. Brazilian J Infect Dis. 2013;17(4):464-479.

2. von Wyl V, Klimkait T, Yerly S, et al; Swiss HIV Cohort Study. Adherence as a predictor of the development of class-specific resistance mutations: the Swiss HIV Cohort Study. PLoS One. 2013;8(10): e77691.

3. Nemes MI, Castanheira ER, Helena ET, et al. Adesão ao tratamento, acesso e qualidade da assistência em Aids no Brasil [Treatment adherence, access and AIDS assistance quality in Brazil]. Rev Assoc Med Bras. 2009;55(2):207-212. Portuguese.

4. Nemes MIB, Carvalho HB, Souza MFM. Antiretroviral therapy adherence in Brazil. AIDS. 2004;18(Suppl 3):S15-S20.

5. Cantudo-Cuenca MR, Jiménez-Galán R, Almeida-González CV, Morillo-Verdugo R. Concurrent use of comedications reduces adherence to antiretroviral therapy among HIV-infected patients. $J$ Manag Care Spec Pharm. 2014;20(8):844-850.

6. Tsega B, Srikanth BA, Shewamene Z. Determinants of non-adherence to antiretroviral therapy in adult hospitalized patients, Northwest Ethiopia. Patient Prefer Adherence. 2015;9:373-380.

7. Ankrah DN, Koster ES, Mantel-Teeuwisse AK, Arhinful DK, Agyepong IA, Lartey M. Facilitators and barriers to antiretroviral therapy adherence among adolescents in Ghana. Patient Prefer Adherence. 2016;10:329-337.

8. Guimarães MDC, Rocha GM, Campos LN, et al. Difficulties reported by HIV-infected patients using antiretroviral therapy in Brazil. Clin (São Paulo). 2008;63(2):165-172.

9. Bartlett JA. Addressing the challenges of adherence. J Acquir Immune Defic Syndr. 2002;29(Suppl 1):S2-S10.

10. Shuter J, Sarlo JA, Kanmaz TJ, Rode RA, Zingman BS. HIV-infected patients receiving lopinavir/ritonavir-based antiretroviral therapy achieve high rates of virologic suppression despite adherence rates less than 95\%. J Acquir Immune Defic Syndr. 2007;45(1):4-8.

11. Bangsberg DR. Less than $95 \%$ adherence to nonnucleoside reversetranscriptase inhibitor therapy can lead to viral suppression. Clin Infect Dis. 2006;43(7):939-941.

12. Polejack L, Seidl EMF. Monitoramento e avaliação da adesão ao tratamento antirretroviral para HIV/AIDS: desafios e possibilidades [Monitoring and evaluation of adherence to ARV treatment for HIV/ AIDS: challenges and possibilities]. Cien Saude Colet. 2010;15(Suppl 1):1201-1208. Portuguese.

13. Vajpayee M, Mohan T. Current practices in laboratory monitoring of HIV infection. Indian J Med Res. 2011;134(6):801-822.

14. Knobel H, Alonso J, Casado JL, et al; GEEMA Study Group. Validation of a simplified medication adherence questionnaire in a large cohort of HIV-infected patients: the GEEMA Study. AIDS. 2002;16(4): 605-613.
15. Remor E, Milner-Moskovics J, Preussler G. Adaptação brasileira do Cuestionario para la Evaluación de la Adhesión al Tratamiento Antiretroviral [Brazilian adaptation of the Assessment of Adherence to Antiretroviral Therapy Questionnaire]. Rev Saude Publica. 2007;41(5):685-694. Portuguese.

16. BRASIL. Ministério da Saúde. Secretaria de Vigilância em Saúde. Departamento de DST AIDS e Hepatites Virais. Adesão ao tratamento antirretroviral no Brasil: coletânea de estudos do projeto ATAR: projeto ATAR (série b. Textos básicos de saúde) [Adherence to antiretroviral treatment in Brazil: study collection of the ATAR project: ATAR project]. Ministério da Saúde; 2010:408.

17. BRASIL. Ministério da Saúde. Secretaria de Vigilância em Saúde. Departamento de DST AIDS e Hepatites Virais. Protocolo clínico e Diretrizes Terapêticas para Manejo da Infecção pelo HIV em Adultos [Clinical protocol and therapeutic guidelines for managing HIV infection in adults] [Internet]. Brasília (DF): Ministério da Saúde; 2015:53-57. Available from: http://www.aids.gov.br/sites/default/files/ anexos/publicacao/2013/55308/protocolofinal_31_7_2015_pdf_31327. pdf. Accessed April 18, 2016.

18. Mastroianni PDC, Lucchetta RC, Sarra JDR, Galduróz JCF. Estoque doméstico e uso de medicamentos em uma população cadastrada na estratégia saúde da família no Brasil [Household storage and use of medications in a population served by the family health strategy in Brazil]. Rev Panam Salud Pública. 2011;29(5):358-364. Portuguese.

19. Gao X, Nau DP, Rosenbluth SA, Scott V, Woodward C. The relationship of disease severity, health beliefs and medication adherence among HIV patients. AIDS Care. 2000;12(4):387-398.

20. Kalichman SC, Benotsch E, Suarez T, Catz S, Miller J, Rompa D. Health literacy and health-related knowledge among persons living with HIV/AIDS. Am J Prev Med. 2000;18(4):325-331.

21. Colombrini MRC, Lopes MHBDM, de Figueiredo RM. Adesão à terapia antiretroviral para HIV/AIDS [Adherence to the antiretroviral therapy for HIV/AIDS]. Rev Esc Enferm USP. 2006;40(4):576-581. Portuguese.

22. Seidl EMF, Tróccoli BT. Desenvolvimento de escala para avaliação do suporte social em HIV/aids [Development of a scale for evaluating the social support in HIV/AIDS]. Psicol Teor e Pesqui. 2006;22(3): 317-326.

23. Nachega JB, Morroni C, Zuniga JM, et al. HIV treatment adherence, patient health literacy, and health care provider-patient communication: results from the 2010 AIDS Treatment for Life International Survey. J Int Assoc Physicians AIDS Care (Chic). 2012;11(2):128-133.

24. Wolf MS, Davis TC, Osborn CY, Skripkauskas S, Bennett CL, Makoul G. Literacy, self-efficacy, and HIV medication adherence. Patient Educ Couns. 2007;65(2):253-260.

25. Mastroianni PC, Machuca M. La pedagogía de la autonomía para optimizar los resultados del tratamiento farmacéutico [Teaching autonomy in order to optimize drug therapy outcomes]. Rev Panam Salud Publica. 2012;32(5):389-390. Spanish.

26. Conn VS, Ruppar TM, Enriquez M, Cooper PS. Patient-centered outcomes of medication adherence interventions: systematic review and meta-analysis. Value Heal. 2016;19(2):277-285.

27. Nachega JB, Mugavero MJ, Zeier M, Vitória M, Gallant JE. Treatment simplification in HIV-infected adults as a strategy to prevent toxicity, improve adherence, quality of life and decrease healthcare costs. Patient Prefer Adherence. 2011;5:357-367.

28. Saberi P, Dong BJ, Johnson MO, Greenblatt RM, Cocohoba JM. The impact of HIV clinical pharmacists on HIV treatment outcomes: a systematic review. Patient Prefer Adherence. 2012;6:297-322.

29. Carnevale RC, de Godoi Rezende Costa Molino C, Visacri MB, Mazzola PG, Moriel P. Cost analysis of pharmaceutical care provided to HIV-infected patients: an ambispective controlled study. Daru. 2015; 23(1):13. 
Patient Preference and Adherence

Dovepress

\section{Publish your work in this journal}

Patient Preference and Adherence is an international, peer-reviewed, open access journal that focuses on the growing importance of patient preference and adherence throughout the therapeutic continuum. Patient satisfaction, acceptability, quality of life, compliance, persistence and their role in developing new therapeutic modalities and compounds to optimize

Submit your manuscript here: http://www.dovepress.com/patient-preference-and-acherence-journa clinical outcomes for existing disease states are major areas of interest for the journal. This journal has been accepted for indexing on PubMed Central. The manuscript management system is completely online and includes a very quick and fair peer-review system, which is all easy to use. Visit http://www. dovepress.com/testimonials.php to read real quotes from published authors. 